\title{
DNAFoil, a novel technology for the rapid detection of food pathogens: Preliminary validation on
}

\section{Salmonella and Listeria monocytogenes}

\begin{abstract}
Aly Farag El Sheikha $a^{1,2,3,4,5}$
${ }^{1}$ College of Bioscience and Bioengineering, Jiangxi Agricultural University, 1101 Zhimin Road, Nanchang 330045, China; ${ }^{2}$ School of Nutrition Sciences, Faculty of Health Sciences, University of Ottawa, 25 University Private Ottawa, ON K1N 6N5, Canada; ${ }^{3}$ Bioengineering and Technological Research Centre for Edible and Medicinal Fungi, Jiangxi Agricultural University, 1101 Zhimin Road, Nanchang 330045, China; ${ }^{4}$ Jiangxi Key Laboratory for Conservation and Utilization of Fungal Resources, Jiangxi Agricultural University, 1101 Zhimin Road, Nanchang 330045, China; ${ }^{5}$ Department of Food Science and Technology, Faculty of Agriculture, Minufiya University, 32511 Shibin El Kom, Minufiya Government, Egypt
\end{abstract}

*Corresponding Author: Aly Farag El Sheikha, College of Bioscience and Bioengineering, Jiangxi Agricultural University, 1101 Zhimin Road, Nanchang 330045, Jiangxi, China. Email: elsheikha_aly@yahoo.com

Received: 1 January 2021; Accepted: 4 April 2021; Published: 19 April 2021

(C) 2021 Codon Publications

\section{OPEN ACCESS CC)(요 ORIGINAL ARTICLE}

\begin{abstract}
Over the past decades, several tools have been developed for food pathogen detection, including proteomics, metabolomics, immunological, biosensor, and nucleic acid-based approaches. Although these techniques are reliable and precise, they are time-consuming, technically challenging, and costly. Hence, it is necessary to develop rapid techniques for food pathogen detection, which can be performed at the household level. DNAFoil mechanism is a portable, completely self-administered, on-site DNA test that does not need expensive instruments or settings to confirm food pathogen detection in as little as $30 \mathrm{~min}$. DNAFoil was used successfully for detecting food contamination and adulteration with pork derivatives (down to $0.1 \%$ ) and vegetal components (down to $0.01 \%$ ), respectively. In this study, initial validation experiments of DNAFoil were investigated to detect Listeria monocytogenes and Salmonella contamination. To confirm the specificity of the proposed method toward Salmonella, 18 different Salmonella strains, 6 non-Salmonella bacteria, and 2 fungi were investigated; also, in the case of Listeria monocytogenes, five bacterial strains, two fungi, and Listeria monocytogenes were investigated. The results stated that the Swiss Decode Salmonella and L. monocytogenes solutions can detect as few as 1 and 10 copies of DNA per microliter, respectively. The results also showed that the accuracy of our method ranges between 92 and 100\%, while the precision value ranged between 88 and 100\%. In terms of quality control applicability, DNAFoil Salmonella and Listeria monocytogenes reactions could be visually detected with the naked eye using a lateral flow strip, which could be used for in-place quality control during manufacturing and also can be used for more lab tests. In terms of cost, DNAFoil is usually much cheaper than the traditional detection methods. Therefore, DNAFoil is proposed as a promising and universal detection technology for food pathogens.
\end{abstract}

Keywords: DNAFoil technology; food pathogen detection techniques; food safety; foodborne diseases; health and economics threats

\section{Introduction}

It is well-known that food safety is affected by many factors and variables, including, for example, globalization of food trade, population increase in the world, change in the lifestyle of consumers, climate changes, and the accompanying rapid changes in food systems. International trade means that unsafe food can be distributed widely (Pinu, 2016; WHO, 2020). Recently, many food-borne disease outbreaks in the world, the most 
prominent of which were due to several microbial species, for example, Listeria monocytogenes, Escherichia coli, Campylobacter jejuni, Salmonella sp., Shigella sp., have proven that food safety is under severe threat from food pathogens (Bintsis, 2017; Chlebicz and Śliżewska, 2018; Faour-Klingbeil and Todd, 2020). Unsafe food containing food pathogens, that is, bacteria, viruses, parasites, or fungi, can cause different diseases ranging from diarrhea to cancers (Dwivedi and Jaykus, 2011; Food Safety Education Program, 2016; WHO, 2020).

Centers for Disease Control and Prevention (CDC) estimates that each year 48 million people get sick from foodborne diseases, 128,000 are hospitalized, and 3000 die. Foodborne pathogens cause diseases and deaths in all populations, particularly in groups at risk such as infants, children, elderly, and immunocompromised persons (CDC, 2020; FDA, 2021; WHO, 2020, 2021). The most common microorganisms responsible for the major foodborne illnesses are shown in Table 1.

In addition to the severe health risks caused by foodborne illnesses, they may also threaten international trade and cause significant economic losses. This has been confirmed by the reports received from the USDA's Economic Research Service. These reports indicated that foodborne illnesses cost the United States more than $\$ 15.6$ billion.
Salmonella tops the list of foodborne pathogens, with a treatment cost equivalent to $\$ 3.6$ billion, followed by Listeria monocytogenes, which equals $\$ 2.8$ billion, and then Escherichia coli with a value of \$271 million (USDA ERS, 2014). This is in addition to the cost of recalls of the products as well (Tyco Integrated Security, 2012).

Hence, there is an urgent need to develop simple, sensitive, specific, robust, reliable, inexpensive, and rapid techniques for food pathogen detection, can perform at the household level and ensure food safety. These requirements comply with new, portable, completely self-administered, on-site DNA test technology called "DNAFoil technology," which does not need expensive equipment or laboratory settings to get the final results in as little as $30 \mathrm{~min}$ (El Sheikha, 2019). Additionally, DNAFoil technique has proven to be effective in:

- Detecting food contamination through its ability to detect pork contamination in beef as lower as $0.1 \%$ (Meat and Livestock Australia Limited "MLA", 2018);

- Detecting of food adulteration through its ability to detect the adulteration of milk products by vegetal materials as lower as $0.01 \%$ (Aronoff et al., 2018).

Through five steps (Figure 1), it can be clearly understood as to how this technique works. Sample preparation

Table 1. The most common microorganisms responsible for the major foodborne illnesses.

\begin{tabular}{|c|c|c|c|c|}
\hline $\begin{array}{l}\text { Foodborne illness } \\
\text { or toxin }\end{array}$ & $\begin{array}{l}\text { Associated } \\
\text { microorganism }\end{array}$ & Health risks & $\begin{array}{l}\text { Most population } \\
\text { group(s) affected }\end{array}$ & Reference \\
\hline Listeriosis & $\begin{array}{l}\text { Listeria } \\
\text { monocytogenes }\end{array}$ & $\begin{array}{l}\text { Meningitis, mild illness in pregnant } \\
\text { women, in babies (miscarriage, stillbirth, } \\
\text { premature birth, potentially fatal infection } \\
\text { after birth) }\end{array}$ & $\begin{array}{l}\text { Pregnant women, } \\
\text { newborns, the elderly, } \\
\text { immuno-compromised } \\
\text { individuals }\end{array}$ & $\begin{array}{l}\text { Buchanan et al. (2017), } \\
\text { Mayo Clinic (2020a) }\end{array}$ \\
\hline Salmonellosis & Salmonella spp. & $\begin{array}{l}\text { Typhoid fever, inflammatory bowel } \\
\text { disease, stomach or bowel disorders }\end{array}$ & All groups & $\begin{array}{l}\text { Bintsis (2017), Mayo Clinic } \\
\text { (2019) }\end{array}$ \\
\hline Shigellosis & Shigella spp. & $\begin{array}{l}\text { Dehydration, seizures, rectal prolapse, } \\
\text { hemolytic uremic syndrome, toxic } \\
\text { megacolon, reactive arthritis, bloodstream } \\
\text { infections (bacteremia) }\end{array}$ & $\begin{array}{l}\text { Malnourished children, } \\
\text { immuno-compromised } \\
\text { individuals, the elderly }\end{array}$ & $\begin{array}{l}\text { NCBI (2017), Mayo Clinic } \\
\text { (2020b) }\end{array}$ \\
\hline Campylobacteriosis & $\begin{array}{l}\text { Campylobacter } \\
\text { spp. }\end{array}$ & $\begin{array}{l}\text { Mild to severe diarrhea, bloody diarrhea, } \\
\text { stomach pain, cramps, nausea and/or } \\
\text { vomiting, fever, muscle pain }\end{array}$ & All groups & $\begin{array}{l}\text { Bintsis (2017), Ontario } \\
\text { Ministry of Health and } \\
\text { Long-Term Care (2020) }\end{array}$ \\
\hline Botulism & $\begin{array}{l}\text { Clostridium } \\
\text { botulinum }\end{array}$ & $\begin{array}{l}\text { Breathing problems, trouble swallowing, } \\
\text { muscle weakness, slurred speech, } \\
\text { headache, nausea }\end{array}$ & All groups & $\begin{array}{l}\text { Bintsis (2017), Rasetti- } \\
\text { Escargueil (2020) }\end{array}$ \\
\hline Toxoplasmosis & $\begin{array}{l}\text { Toxoplasma } \\
\text { gondii }\end{array}$ & $\begin{array}{l}\text { Headache, seizures, lung problems, } \\
\text { severe eye infections, e.g., inflammation } \\
\text { of retina, enlarged liver and spleen }\end{array}$ & $\begin{array}{l}\text { All groups, especially } \\
\text { babies, immuno- } \\
\text { compromised individuals }\end{array}$ & $\begin{array}{l}\text { EFSA and ECDC (2016), } \\
\text { Mayo Clinic (2020c) }\end{array}$ \\
\hline Yersiniosis & Yersinia spp. & $\begin{array}{l}\text { Fever, abdominal pain, diarrhea (which is } \\
\text { often bloody) }\end{array}$ & $\begin{array}{l}\text { All groups, especially } \\
\text { children, adults }\end{array}$ & $\begin{array}{l}\text { EFSA and ECDC (2016), } \\
\text { Ontario Ministry of Health } \\
\text { and Long-Term Care (2018) }\end{array}$ \\
\hline Amoebiasis & $\begin{array}{l}\text { Entamoeba } \\
\text { histolytica }\end{array}$ & $\begin{array}{l}\text { Bowel perforation, gastrointestinal } \\
\text { bleeding, stricture formation, } \\
\text { intussusception, peritonitis, empyema }\end{array}$ & All groups & NCBI (2016), Park (2015) \\
\hline
\end{tabular}


without the need to be pre-enriched before analysis is considered the main obstacle in most methods, but the enrichment remains essential for the revival of stressed or injured cells (Cossarizza et al., 2017; Valderrama et al., 2016). But, through the DNAFoil mechanism, the sample preparation and DNA extraction stages were completed in a single step without the need to use spin-columns and centrifuges. For the amplification stage, crosscontamination is one of the difficulties faced by the commercially available kits used to detect food pathogens, that is, Salmonella and Listeria monocytogenes (Baraketi et al., 2018). In contrast to what happened using the DNAFoil technique, it is obvious that the DNA target amplification is done in one pot master mix without requiring trained staff, using thermos-cycling and cold chain. For the final stage (DNA detection stage), there are several problems generated from DNA electrophoresis and staining such as it being time-consuming, gel preparation, smearing, mutagenicity, toxicity, lower efficiency, etc. (Drabik et al., 2016; Hall, 2020). DNAFoil as a detection method during the final stage provides the test strip material, which allows for transport by a capillary force of the target DNA through the detection surface, allowing the target to hybridize specifically to their complementary capture sequences (target DNA fragments are captured in a band). Conjugation of micrometer-sized beads to DNA permits the results to be visualized by the naked eye (visible color reaction), enabling immediate, simple to interpret, cost-efficient, and on-site detection, while eliminating the need for advanced expensive instrumentation (El Sheikha, 2019).

Hence, the aim of this study was to investigate initial validation experiments of the DNAFoil technique to detect food pathogens, that is, Salmonella and Listeria monocytogenes.

\section{Materials and Methods}

\section{Reference materials}

Crude bacterial DNA extracts were purchased from the Culture Collection of Switzerland (CCOS), and experiments were conducted at the Swiss Decode labs in Renens, Switzerland. Live strains tested were procured from the Pasteur Institute (France). The strains tested were divided into two groups one for inclusivity and the other for exclusivity toward Salmonella and Listeria monocytogenes as follows. Firstly, the strains were tested for inclusivity and exclusivity toward Salmonella: (i) For inclusivity (Salmonella Montevideo, Salmonella Heidelberg, Salmonella mbandaka, Salmonella enteritidis, Salmonella agona, Salmonella Indiana, Salmonella infantis, Salmonella arizonae IIIa, Salmonella senfentberg, Salmonella cerro, Salmonella Virchow, Salmonella anatum, Salmonella Newport, Salmonella thyphimurium, Salmonella arizonae IIIb, Salmonella saintpaul, Salmonella hadar, Salmonella enteritidis abony); (ii) For exclusivity (Listeria monocytogenes, Bacillus subtilis, Enterococcus faecalis, Escherichia coli, Pseudomonas aeruginosa, Staphylococcus aureus, Aspergillus brasiliensis, Candida albicans). Secondly, the strains tested for inclusivity and exclusivity toward Listeria monocytogenes: (i) For inclusivity (Listeria monocytogenes); (ii) For exclusivity (Bacillus subtilis, Enterococcus faecalis, Escherichia coli, Pseudomonas aeruginosa, Staphylococcus aureus, Aspergillus brasiliensis, Candida albicans). All experiments involving living strains were conducted under BSL2 conditions at the independent microbiology lab in Couternon, France.

\section{Sample preparation, DNA extraction, and amplification stages}

DNAFoil mechanism is depicted in Figure 1. Steps 1 and 2 show the DNA extraction, lysing, neutralizing, and stabilizing processes of $200 \mu \mathrm{L}$ of culture using a barrel without the need to use spin-columns and centrifuges. Briefly, bacteria cells are broken by an alkaline solution that contains chaotropic salts. This allows DNA to be released in the solution. The alkaline $\mathrm{pH}$ of the solution is not compatible with downstream DNA amplification; therefore, a neutralization/stabilization step is added, and it consists of buffering the $\mathrm{pH}$ with a second solution, which also provides monovalent salts that facilitate the DNA amplification reaction. Amplification stage of DNA target is started via step 3; one drop of extracted DNA is transferred to the reaction tube and is incubated in a water bath at $65^{\circ} \mathrm{C}$. Then, using the specific primers and enzymes, the DNA targets will amplify and make multiple copies without using thermos-cycling and cold chain.

\section{End-point assays}

After $30 \mathrm{~min}$ of incubation at $65^{\circ} \mathrm{C}$, DNAFoil strips were dipped into the reaction tube (detection step; 4th step). Migration by lateral-flow caused a positive band's appearance due to colloidal gold concentrating on the DNA capture line without using electrophoresis and staining (detection step; 5th step).

\section{Real-time confirmatory assays}

For real-time assays, $1 \mu \mathrm{L}$ of extract was combined with $24 \mu \mathrm{L}$ of Salmonella and Listeria monocytogenes reactions mix and incubated at $65^{\circ} \mathrm{C}$. Fluorescence (FAM channel) was monitored every $20 \mathrm{~s}$, and the fluorescence signal was plotted over time. 

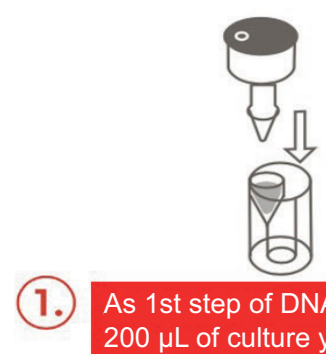

As 1st step of DNA extraction: Get $200 \mu \mathrm{L}$ of culture you want to test for DNA extraction using barrel

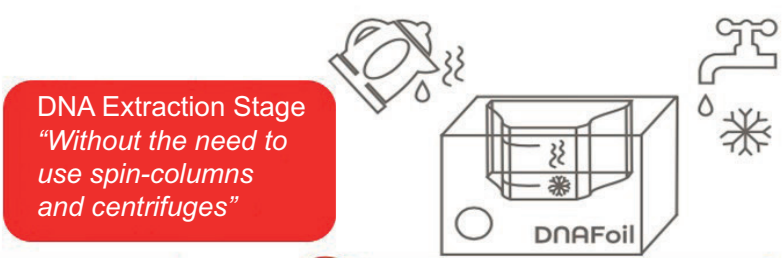

(2.)

As 2nd step of DNA Extraction Mix hot and cold water in the container provided with the test kit

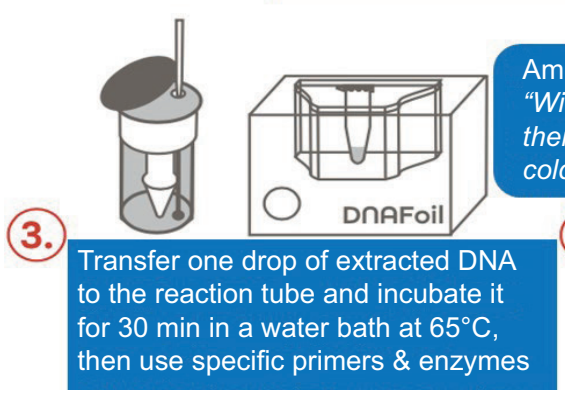

Amplification Stage

"Without using

thermos-cycling \& cold chain"

(4.)

After 30 min of incubation, DNAFoil strip was dipped into reaction tube \& migration by lateral-flow was started
Detection Stage

"Without using

electrophoresis \& staining"

Figure 1. Procedural diagram for the mechanism of food pathogen detection using DNAFoil technology. Source: Adapted from El Sheikha (2019). Reproduced with permission of Elsevier.

\section{Statistical analysis}

All data were presented as the mean value \pm standard deviation (SD) of independent experiments on various days.

\section{Performance metrics}

\section{Accuracy (\%)}

Results from the experimental specificity (Figure 3A and B) were used to calculate the method accuracy using the following equations:

Accuracy $(\%)$ at $10 \mathrm{~min}=\frac{(\mathrm{TP}+\mathrm{TN})}{(\mathrm{TP}+\mathrm{TN}+\mathrm{FP}+\mathrm{FN})} \times 100$

$\operatorname{Accuracy}(\%)$ at $15 \mathrm{~min}=\frac{(\mathrm{TP}+\mathrm{TN})}{(\mathrm{TP}+\mathrm{TN}+\mathrm{FP}+\mathrm{FN})} \times 100$

$\operatorname{Accuracy}(\%)$ at $20 \mathrm{~min}=\frac{(\mathrm{TP}+\mathrm{TN})}{(\mathrm{TP}+\mathrm{TN}+\mathrm{FP}+\mathrm{FN})} \times 100$

where TP, FN, FP, and TN represent the number of true positives, false negatives, false positives, and true negatives, respectively.

\section{Precision (\%)}

Results from the experimental specificity (Figure 3A and B) were used to calculate the method accuracy using the following equations:

$$
\operatorname{Precision}(\%) \text { at } 10 \min =\frac{\mathrm{TP}}{(\mathrm{TP}+\mathrm{FP})} \times 100
$$

$$
\begin{aligned}
& \operatorname{Precision}(\%) \text { at } 15 \mathrm{~min}=\frac{\mathrm{TP}}{(\mathrm{TP}+\mathrm{FP})} \times 100 \\
& \operatorname{Precision}(\%) \text { at } 20 \mathrm{~min}=\frac{\mathrm{TP}}{(\mathrm{TP}+\mathrm{FP})} \times 100
\end{aligned}
$$

where TP, FN, FP, and TN represent the number of true positives, false negatives, false positives, and true negatives, respectively.

\section{Results}

\section{Inclusivity and exclusivity}

To confirm the specificity of our method toward Salmonella, 18 different Salmonella strains, 6 nonSalmonella bacteria, and 2 fungi were investigated; also, in the case of Listeria monocytogenes, five bacterial strains, two fungi, and Listeria monocytogenes were investigated.

Independent microbiology lab prepared cultures containing $10^{8} \mathrm{CFU} / \mathrm{mL}$. Swiss Decode analyzed the broth media in a blinded manner. The amplification time for each strain is reported in Figure 2A and 2B.

The standard amplification time used for our DNAFoil kit is $30 \mathrm{~min}$. Samples for which the amplification signal was not detected after 30 min were considered as negative (no presence of Salmonella or Listeria monocytogenes).

Swiss Decode Salmonella solution positively identified the 18 Salmonella strains after 10 to $13 \mathrm{~min}$ (Figure 2A). 
(A) Not Detected

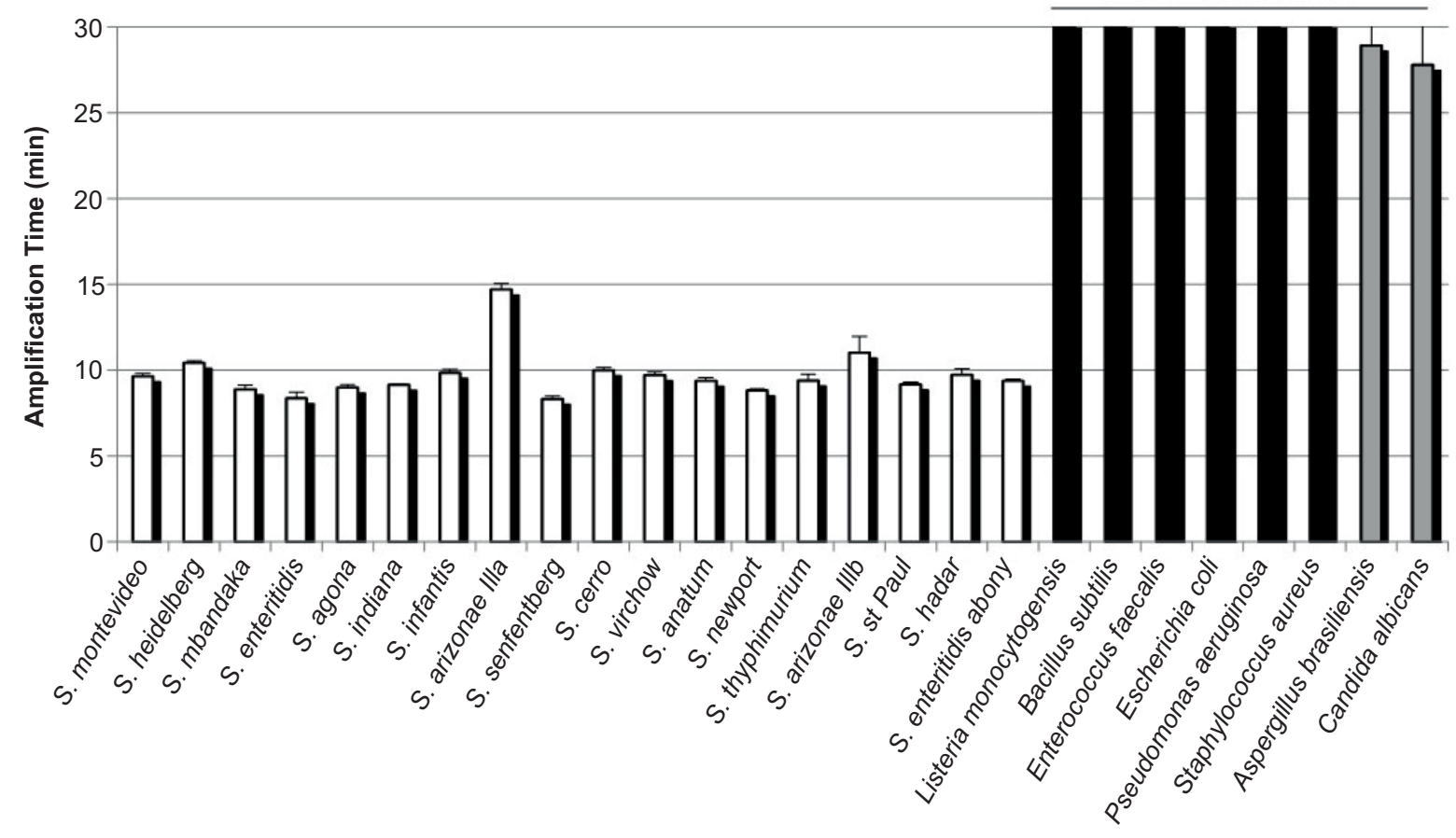

Strains

(B)

Not Detected

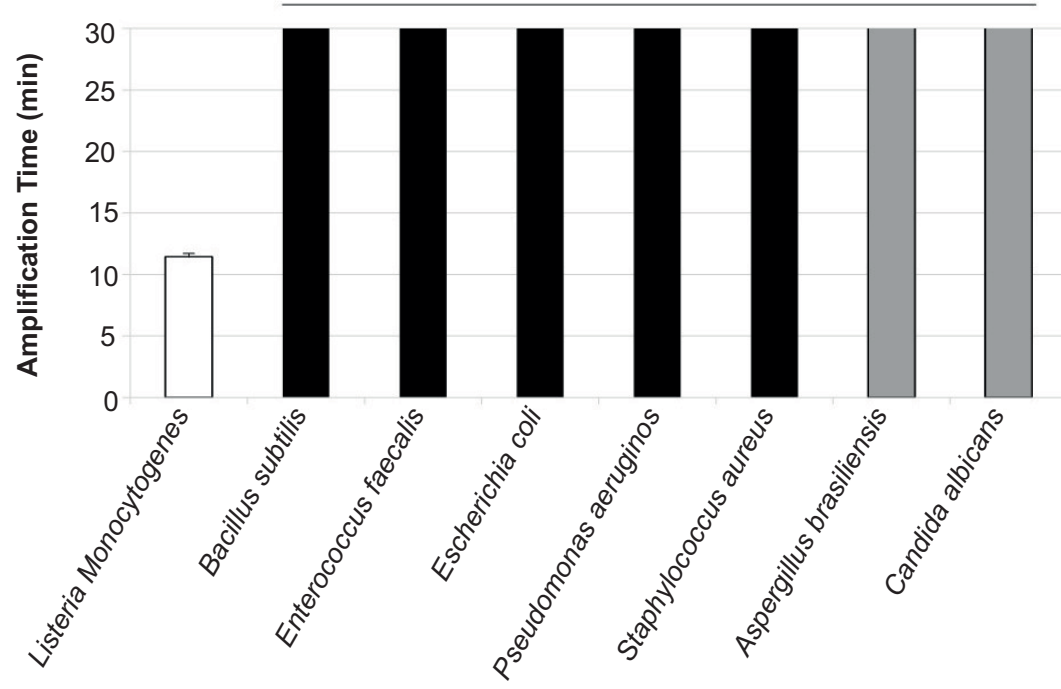

Strains

Figure 2. Amplification time-selectivity experiment. (A) Different cultures of Salmonella (in white), non-Salmonella bacteria (in black), and fungus (in gray) were prepared at an independent microbiology lab. (B) Listeria monocytogenes (in white), different bacterial cultures (in black), and fungus (in gray) were prepared at an independent microbiology lab. Broth media (200 $\mu \mathrm{L}$ ) was withdrawn from cultures containing $10^{8} \mathrm{CFU} / \mathrm{mL}$. Bacteria were lysed according to the standard DNAFoil method. DNA detection was performed with a real-time assay according to the Swiss Decode protocol. Data represent mean \pm SD, $n=3$. 

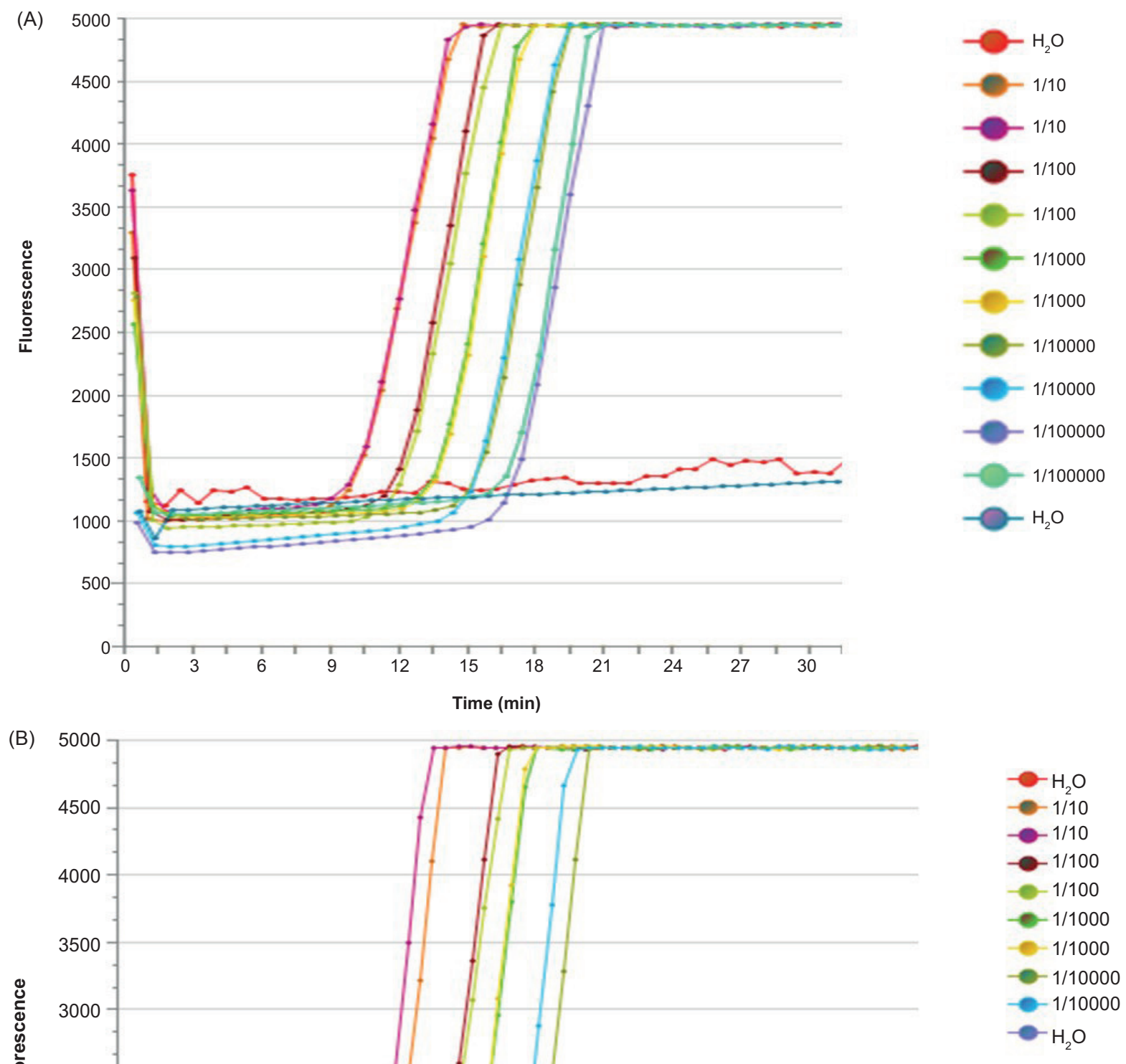
Figure 3. Amplification time-sensitivity experiment. Ten times serial dilution of crude DNA extracts from Salmonella enterica
and Listeria monocytogenes were diluted in $10 \mathrm{mM}$ TRIS pH 8.0 or DNAFoil lysis buffer. One microliter of the lysis solution was taken to run a real-time assay. (A) We can observe that the time needed for the detection of Salmonella increases as the amount of DNA present in the sample decreases. However, the detection time is well below the 30 min used as our standard amplification time. (B) We can observe that the time needed for the detection of Listeria monocytogenes increases as the amount of DNA present in the sample decreases. However, the detection time is well below the $30 \mathrm{~min}$ used as our standard amplification time. 
Other non-Salmonella strain samples were still negative after 30 min. Our method also allowed Salmonella's identification in broth media samples where Salmonella was mixed with several other non-Salmonella strains (data not shown).

Regarding the Listeria monocytogenes, Swiss Decode L. monocytogenes solution positively identified the Listeria monocytogenes strains after 11 min (Figure 2B). The other strain samples were still negative after $30 \mathrm{~min}$.

\section{Limit of detection (LOD) with serial dilutions}

To determine the sensitivity of our method, a serial dilution of crude bacterial DNA extracts was analyzed. Crude extracts for Salmonella Enterica subspc. enterica and Listeria monocytogenes were obtained from CCOS. Crude extracts containing $10^{5} \mathrm{CFU} / \mu \mathrm{L}$ were serially diluted 1:10 either in $10 \mathrm{mM}$ TRIS $\mathrm{pH} 8.0$ or in our DNAFoil lysis buffer. The reactions were analyzed in duplicate by real-time assays (Figure $3 \mathrm{~A}$ and $3 \mathrm{~B}$ ). The results were similar for both dilution methods (data not shown).

\section{Accuracy and precision (\%)}

Accuracy and precision (\%) are calculated to measure the performance of our method to identify Salmonella and Listeria monocytogenes. These results are shown in Figure $3 \mathrm{~A}$ and $3 \mathrm{~B}$. The results also showed that the accuracy of our method ranges between 92 and $100 \%$, while the precision value ranged between 88 and 100\%.

\section{Point-of-need detection with lateral flow}

As real-time thermocyclers may not be present at the point-of-need (i.e., factory), we verified if the DNAFoil Salmonella and Listeria monocytogenes reactions could be visually detected with the naked eye using a lateral flow strip. Serial dilutions of Salmonella enterica and Listeria monocytogenes extracts were prepared and amplified as before. After $30 \mathrm{~min}$ of amplification at $65^{\circ} \mathrm{C}$, the results were confirmed with DNAFoil strips (Figure 4A and 4B).

\section{Discussion}

The detection of foodborne pathogens has historically been culture-, or conventional-, or cultural-, or goldstandard-based methods, which were used since the inception of microbiological sampling (Adzitey and Huda, 2010, 2011; Bhunia, 2014). These methods mainly involve enrichment (pre-enrichment and/or selective

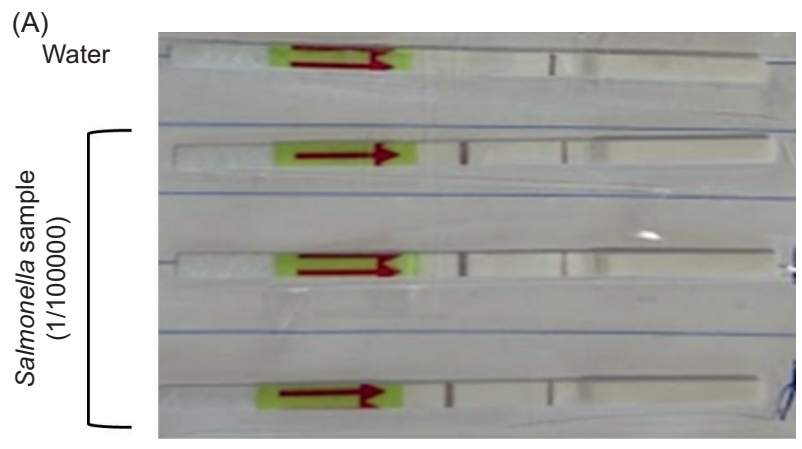

(B)

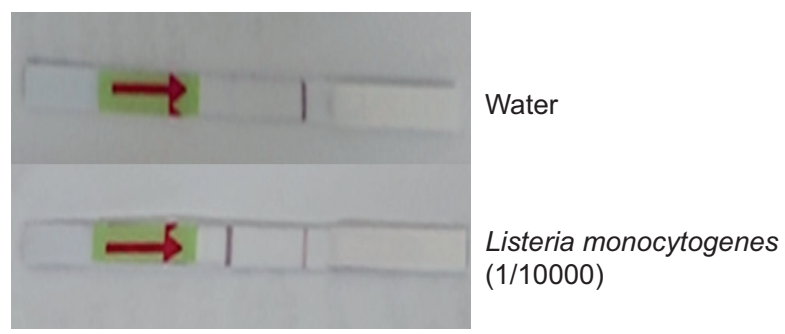

Figure 4. Strips results. (A) Amplified samples from Salmonella dilution 1/100,000 were applied on DNAFoil strips (triplicate). A few minutes later, we could see bands appearing. The band on the left confirmed the presence of Salmonella, whereas the band on the right is the positive control of the strips. (B) Amplified samples from Listeria monocytogenes dilution $1 / 10,000$ were applied on DNAFoil strips. Four minutes later, we could see bands appearing. The band on the left confirmed the presence of Listeria monocytogenes, whereas the band on the right is the positive control of the strips.

enrichment) followed by biochemical tests (metabolic fingerprinting), molecular tests (typically PCR [polymerase chain reaction]), or mass spectrometry (Adzitey et al., 2011; Corry et al., 2003; Ellis et al., 2019) to confirm that the isolate is indeed the pathogen of interest. The gold-standard-based methods have the advantages of being inexpensive, detecting only viable pathogens, and yielding isolates that can further be studied (Adzitey and Huda, 2011; Engberg et al., 2000). However, they are cumbersome, relatively slow, and less efficient (Foddai and Grant, 2020; Jasson et al., 2010; Keramas et al., 2004; Li and Zhu, 2017; Myint et al., 2006). Regarding the biochemical and mass spectrometry methods, they are rapid, sensitive, and accurate techniques that involve the analysis of entire microbial cells or their extracts (Beale et al., 2014; Cevallos-Cevallos et al., 2011; Singh et al., 2011; Singhal et al., 2015; Toscano et al., 2018; Wu et al., 2016; Yang et al., 2015). However, they are labor-intensive, costly, and the reliance on existing spectral databases of the mass fingerprints of known microbes makes mass spectrometry techniques incapable of identifying new species (Anderson et al., 2012; El Sheikha and Hu, 2020; Jadhav et al., 2018; Mirmajlessi et al., 2015; Reta et al., 2020). Molecular techniques have the advantage of being 
rapid, less laborious, more sensitive, specific, and efficient, compared to the conventional method (Keramas et al., 2004; Magistrado et al., 2001). Nonetheless, certain components/compounds in foods such as fats, lipids, and salts, enrichment media, or DNA extraction solution can inhibit the sensitivity of PCR-based methods (El Sheikha, 2010; Rossen et al., 1992; Wilson, 1997).

To overcome the limitations of traditional methods used for pathogen detection from the side and from the other side to meet industrial and commercial food needs, there is an urgent need for fast, sensitive, accurate, and more efficient detection methods in terms of saving time, labor, and preventing human errors (Baraketi et al., 2018; Law et al., 2015; Mandal et al., 2011; Rajapaksha et al., 2019).

Hence, the importance of answering the principal question, namely, why is DNAFoil technology proposed to detect food pathogens? This question is the hypothesis on which the research idea was based, and which the results of this study approved and provided the answers as follows:

\section{DNAFoil is a fast, accurate, precise, sensitive, and reliable technique}

As a new technology that needs assessment, the "realtime" amplification technology (real-time PCR) is used to evaluate the efficacy and accuracy of DNAFoil technology (El Sheikha, 2019). Aronoff et al. (2018) reported that the efficiency of DNAFoil kit used to detect the vegetal material in milk products (DNAFoil UniPlant) was confirmed using real-time PCR assays. The same authors concluded that the DNAFoil UniPlant kit provides a quick and reliable method to validate product content with less than $1 \%$ adulteration of any product, confirming identity and purity in $30 \mathrm{~min}$, without lab equipment, technicians, or scientists. The final report provided by Meat and Livestock Australia Limited (MLA) (2018) illustrated that the DNAFoil kit is able to detect pork contamination in beef as lower as $0.1 \%$.

The present study illustrated that the DNAFoil is a fast-detection technique of Salmonella and Listeria monocytogenes that can get the final results in as little as $30 \mathrm{~min}$. In addition, the results of this study stated that the Swiss Decode Salmonella and L. monocytogenes solutions can detect as few as 1 and 10 copies of DNA per microliter, respectively. However, the commercially available kits used to detect food pathogens, that is Salmonella and Listeria monocytogenes, which are based on nucleic acid for detection, are characterized by reliability, high specificity, and sensitivity; they are limited by the difficulties of:

- differentiating the viable cells from nonculturable cells; - the primers' design.

Moreover, these kits require trained staff to avoid cross-contamination (Baraketi et al., 2018). Table 2 evaluates the commercial kits used to detect Salmonella and Listeria monocytogenes. In terms of performance metrics (accuracy, precision \%), the results show promising performance, to be used for Salmonella and Listeria monocytogenes detection.

\section{The DNAFoil technology is efficient in terms of cost and quality control applicability}

In terms of cost. DNAFoil is available to the partners (academic and industry) that accede to the Early Access Program. The fee to enter the Early Access Program is

Table 2. Commercially available kits based on nucleic acid methods for the detection of foodborne pathogens.*

\begin{tabular}{|c|c|c|c|c|}
\hline Pathogen & Commercially available kits & Sensitivity & Sample matrix & Company \\
\hline \multirow[t]{3}{*}{ Salmonella sp. } & $\begin{array}{l}\text { BAX® System Standard PCR assays } \\
\text { for Salmonella }\end{array}$ & $\begin{array}{l}10^{4} \mathrm{CFU} / \mathrm{mL} \text {, after } \\
\text { enrichment }\end{array}$ & $\begin{array}{l}\text { Poultry, dairy, fruits, vegetables, bakery } \\
\text { products, pet food, environmental samples }\end{array}$ & HYGIENA \\
\hline & $\begin{array}{l}\text { BAX® System Real-time PCR assay } \\
\text { for Salmonella }\end{array}$ & $\begin{array}{l}10^{4} \mathrm{CFU} / \mathrm{mL} \text {, after } \\
\text { enrichment }\end{array}$ & $\begin{array}{l}\text { Meat, poultry, dairy, fruits, vegetables, bakery } \\
\text { products, pet food, environmental samples }\end{array}$ & HYGIENA \\
\hline & GeneQuence® for Salmonella & $1-5 \mathrm{CFU} / 25 \mathrm{~g}$ & Food and environmental samples & HYGIENA \\
\hline \multirow[t]{4}{*}{$\begin{array}{l}\text { Listeria } \\
\text { monocytogenes }\end{array}$} & $\begin{array}{l}\text { BAX® System PCR Assay for } L \text {. } \\
\text { monocytogenes }\end{array}$ & $\begin{array}{l}10^{5} \mathrm{CFU} / \mathrm{mL} \text {, after } \\
\text { enrichment }\end{array}$ & Variety of food types & HYGIENA \\
\hline & $\begin{array}{l}\text { BAX® System PCR Assay for } \\
\text { L. monocytogenes } 24 \mathrm{E}\end{array}$ & $\begin{array}{l}10^{4} \mathrm{CFU} / \mathrm{mL} \text {, after } \\
\text { enrichment }\end{array}$ & Dairy, meat, fish, vegetables, environmentals & HYGIENA \\
\hline & $\begin{array}{l}\text { BAX® System Real-Time PCR Assay } \\
\text { for } L \text {. monocytogenes }\end{array}$ & $\begin{array}{l}10^{4} \mathrm{CFU} / \mathrm{mL} \text {, after } \\
\text { enrichment }\end{array}$ & $\begin{array}{l}\text { Dairy, ready-to-eat meat, seafood, } \\
\text { vegetables, environmental samples }\end{array}$ & HYGIENA \\
\hline & GeneQuence® for L. monocytogenes & $1-5 \mathrm{CFU} / 26 \mathrm{~g}$ & Food and environmental samples & NEOGEN \\
\hline
\end{tabular}


$€ 990$ and the program makes access free of charge for a kit of 5 tests. The final cost per test is negotiable, and it is usually much cheaper than the traditional detection methods (Aronoff et al., 2018; Lüdin et al., 2018).

In terms of quality control applicability. The DNAFoil output gives a $( \pm)$ answer, for example, while using DNAFoil Pork Test Kit, a positive result indicates the presence of porcine DNA in the sample tested. This is enough for an inspector to take instant action. The strips with the results can be stored as evidence to prove that adequate controls are in place during manufacturing. In the case of litigations, the Swiss Federal Lab concluded that DNA can be easily extracted from the strip, and such DNA can be used for more lab tests (Lüdin et al., 2018).

\section{Conclusions, Remarks, and Future Trends}

In this study, the developed DNAFoil Salmonella and Listeria monocytogenes reactions correctly identify a wide range of Salmonella strains and also Listeria monocytogenes, among other bacterial strains. These reactions are specific and sensitive, with a virtual limit of 1 and 10 CFU detection per reaction for Salmonella and Listeria monocytogenes, respectively. In terms of accuracy and precision, the results show promising performance in which the accuracy ranged between 92 and $100 \%$ and the precision ranged between 88 and 100\%. Real-time PCR may not be present at the point-of-need (i.e., factory); therefore, the DNAFoil Salmonella and Listeria monocytogenes reactions could be visually detected with the naked eye using a lateral flow strip. The strips with the results can be stored for quality control in place during manufacturing and also can be used for more lab tests. The results of the present study revealed and confirmed several advantages that considered DNAFoil fact sheet as follows: the DNAFoil is easy to use and does not require specialized skills to perform testing; the DNAFoil is standalone and does not require laboratory equipment other than a source of boiling water. In the absence of boiling water, the kit is compatible with a standard thermoblock; the DNAFoil detects specifically each target without any cross-reaction; the final results can be interpreted with the naked eye with a lateral flow dipstick without the need for thermocyclers, electrophoresis, and staining.

Food pathogen detection approaches have become ever more substantial for all of the food chain components, that is, consumers, producers, and legislators (El Sheikha, 2015; Hoffmann and Scallan, 2017). The embodiments of food pathogen risks in food products continue to evolve in different forms that have resulted in tremendous improvements in analytical methodologies to detect the food pathogens (Hemalata and Virupakshaiah, 2016).
Although DNA-based techniques have proven to be the best detection tools in food pathogen detection, at the industrial level its practical application has to go a long way (El Sheikha et al., 2018; Zhao et al., 2014). Hence, the demand for a novel, rapid, easy, potent, and universal technology for food pathogen detection is still an urgent need. Therefore, it is hoped that the DNAFoil technology could be a powerful tool that meets all of the requirements for food pathogen detection and its applications either at the household or industrial level.

As a future trend, more applications are recommended for DNAFoil technology as a food pathogen detection tool on different food matrices. Moreover, the DNAFoil test kits for Salmonella and Listeria monocytogenes are qualified for further validation using ISO16140.

\section{Compliance with Ethical Standards}

\section{Acknowledgments}

This research was supported by the Research Start-Up Fund from Jiangxi Agricultural University, China that granted to Prof. Aly El Sheikah (Fund N ${ }^{\circ}$ 9232307245).

\section{Conflict of Interest}

The author declares that there is no conflict of interest.

\section{References}

Adzitey, F. and Huda, N., 2010. Listeria monocytogenes in foods: incidences and possible control measures. African Journal of Microbiology Research 4: 2848-2855. Available at: http://www. academicjournals.org/ajmr

Adzitey, F. and Huda, N., 2011. Campylobacter in poultry: incidences and possible control measures. Research Journal of Microbiology 6: 182-192. https://doi.org/10.3923/jm.2011.182.192

Adzitey, F., Huda, N. and Gulam, R., 2011. Comparison of media for the isolation of Salmonella (XLD and Rambach) and Listeria species (ALOA and Palcam) in naturally contaminated duck samples. Internet Journal of Food Safety 13: 20-25.

Anderson, N.W., Buchan, B.W., Riebe, K.M., Parsons, L.N., Gnacinski, S. and Ledeboer, N.A., 2012. Effects of solid-medium type on routine identification of bacterial isolates by use of matrix-assisted laser desorption ionization-time of flight mass spectrometry. Journal of Clinical Microbiology 50: 1008-1013. https://doi.org/10.1128/JCM.05209-11

Aronoff, R., Vernez, I., Rotman, N. and Rando, G., 2018. Detection of milk adulteration using DNAFoil UniPlant. Application Note: v0.3 Available at: https://www.dropbox.com/s/ho5ich3fpzy5k0s/ application_note_UniPlant_1dec17.docx?dl=0. Accessed 27 January 2021. 
Baraketi, A., Salmieri, S. and Lacroix, M., 2018. Foodborne pathogens detection: persevering worldwide challenge. In: Rinken, $\mathrm{T}$. and Kivirand, K. (eds.) Biosensing technologies for the detection of pathogens-a prospective way for rapid analysis. IntechOpen, Rijeka, Croatia, pp. 53-72. https://doi.org/10.5772/ intechopen.74421

Beale, D.J., Morrison, P.D. and Palombo, E.A., 2014. Detection of Listeria in milk using non-targeted metabolic profiling of Listeria monocytogenes: a proof-of-concept application. Food Control 42: 343-346. https://doi.org/10.1016/j.foodcont.2014.01.022

Bhunia, A., 2014. One day to one hour: how quickly can foodborne pathogens be detected? Future Microbiology 9: 935-946. https://doi.org/10.2217/FMB.14.61

Bintsis, T., 2017. Foodborne pathogens. AIMS Microbiology 3: 529563. https://doi.org/10.3934/microbiol.2017.3.529

Buchanan, R.L., Goris, L.G.M., Hayman, M.M., Jackson, T.C. and Whiting, R.C., 2017. A review of Listeria monocytogenes: an update on outbreaks, virulence, dose-response, ecology, and risk assessments. Food Control 75: 1-13. https://doi.org/10.1016/j. foodcont.2016.12.016

CDC (Centers for Disease Control and Prevention), 2020. Foodborne germs and illnesses. Last updated: March 18, 2020. Available at: https://www.cdc.gov/foodsafety/foodborne-germs. html. Accessed 27 January 2021.

Cevallos-Cevallos, J.M., Danyluk, M.D. and Reyes-De-Corcuera, J.I., 2011. GC-MS based metabolomics for rapid simultaneous detection of Escherichia coli O157: H7, Salmonella Typhimurium, Salmonella Muenchen, and Salmonella Hartford in ground beef and chicken. Journal of Food Science 76: M238-M246. https:// doi.org/10.1111/j.1750-3841.2011.02132.x

Chlebicz, A. and Śliżewska, K., 2018. Campylobacteriosis, salmonellosis, yersiniosis, and listeriosis as zoonotic foodborne diseases: a review. International Journal of Environmental Research and Public Health 15: 863. https://doi.org/10.3390/ijerph15050863

Corry, J.E.L., Atabay, H.I., Forsythe, S.J. and Mansfield, L.P., 2003. Culture media for the isolation of Campylobacters, Helicobacters and Arcobacters. In: Corry, J.E.L., Curtis, G.D.W. and Baird, R.M. (eds.) Handbook of culture media for food microbiology. 2nd ed. Elsevier Science, Amsterdam, pp. 271315. https://doi.org/10.1016/S0079-6352(03)80021-8

Cossarizza, A., Chang, H.-D., Radbruch, A., Akdis, M., Andrä, I., Annunziato, F., et al. 2017. Guidelines for the use of flow cytometry and cell sorting in immunological studies. European Journal of Immunology 47: 1584-1797. https://doi.org/10.1002/ eji.201646632

Drabik, A., Bodzoń-Kułakowska, A. and Silberring, J., 2016. Gel electrophoresis. In: Ciborowski, P. and Silberring, J. (eds.) Proteomic profiling and analytical chemistry. 2nd ed. Elsevier, Amsterdam, Netherlands, pp. 115-143. https://doi.org/10.1016/ B978-0-444-63688-1.00007-0

Dwivedi, H.P. and Jaykus, L., 2011. Detection of pathogens in foods: the current state-of-the-art and future directions. Critical Reviews in Microbiology 37: 40-63. https://doi.org/10.3109/10 4084.1X.2010.506430

EFSA and ECDC (European Food Safety Authority and European Centre for Disease Prevention and Control), 2016. The European
Union summary report on trends and sources of zoonoses, zoonotic agents and food-borne outbreaks in 2015. EFSA Journal 14: 4634-4865. https://doi.org/10.2903/j.efsa.2016.4634

El Sheikha, A.F., 2010. Determination of geographical origin of Shea tree and Physalis fruits by using the genetic fingerprints of the microbial community by PCR/DGGE. Analysis of biological properties of some fruit extracts. PhD thesis. University of Montpellier 2, Montpellier, France. Available at: https://docplayer. fr/608448-Universite-montpellier-ii-sciences-et-techniquesdu-languedoc-t-h-e-s-e-pour-obtenir-le-grade-de-docteur-de-1universite-montpellier-ii.html. Accessed 27 January 2021.

El Sheikha, A.F., 2015. Food safety issues in Saudi Arabia. Nutrition and Food Technology: Open Access 1: 1-4. https://doi. org/10.16966/nftoa.103

El Sheikha, A.F., 2019. DNAFoil: novel technology for the rapid detection of food adulteration. Trends in Food Science \& Technology 86: 544-552. https://doi.org/10.1016/j.tifs.2018. 11.012

El Sheikha, A.F. and Hu, D.-H., 2020. Molecular techniques reveal more secrets of fermented foods. Critical Reviews in Food Science and Nutrition 60: 11-32. https://doi.org/10.1080/10408 398.2018.1506906

El Sheikha, A.F., Levin, R.E. and Xu, J., 2018. Molecular techniques in food biology: safety, biotechnology, authenticity \& traceability. 1st ed. John Wiley \& Sons, Ltd., Chichester, UK. https://doi. org/10.1002/9781119374.633

Ellis, D.I., Muhamadali, H., Chisanga, M. and Goodacre, R., 2019. Omics methods for the detection of foodborne pathogens. In: Melton, L., Shahidi, F. and Varelis, P. (eds.) Encyclopedia of food chemistry. Academic Press, Oxford, pp. 364-370. https://doi. org/10.1016/B978-0-08-100596-5.21793-9

Engberg, J., On, S.L.W., Harrington, C.S. and Gerner-Smidt, P., 2000. Prevalence of Campylobacter, Arcobacter, Helicobacter and Sutterella spp. in human faecal samples as estimated by reevaluating of isolation methods for Campylobacters. Journal of Clinical Microbiology 38: 286-291.

Faour-Klingbeil, D. and Todd, E.C.D., 2020. Prevention and control of foodborne diseases in Middle-East North African countries: review of national control systems. International Journal of Environmental Research and Public Health 17: 70. https://doi. org/10.3390/ijerph17010070

FDA (U.S. Food and Drug Administration), 2021. Most common foodborne illnesses. Available at: https://www.fda.gov/ files/food/published/Most-Common-Foodborne-Illnesses\%28PDF\%29.pdf. Accessed 27 January 2021.

Foddai, A.C.G. and Grant, I.R., 2020. Methods for detection of viable foodborne pathogens: current state-of-art and future prospects. Applied Microbiology and Biotechnology 104: 42814288. https://doi.org/10.1007/s00253-020-10542-x

Food Safety Education Program, 2016. Causes and prevention of foodborne illness. Updated 12/2016. Available at: https://web. uri.edu/foodsafety/cause-and-prevention-of-foodborne-illness/. Accessed 27 January 2021.

Hall, A.C., 2020. A comparison of DNA stains and staining methods for Agarose Gel Electrophoresis. https://doi.org/10.1101/568253 (In press). 
Hemalata, V.B. and Virupakshaiah, D.B.M., 2016. Isolation and identification of food borne pathogens from spoiled food samples. International Journal of Current Microbiology and Applied Sciences 5: 1017-1025. https://doi.org/10.20546/ ijcmas.2016.506.108

Hoffmann, S. and Scallan, E., 2017. Epidemiology, cost, and risk analysis of foodborne disease. In: Dodd, C.E.R., Aldsworth, T., Stein, R.A., Cliver, D.O. and Riemann, H.P. (eds.) Foodborne diseases. 3rd ed. Academic Press, Elsevier, London, UK, pp. 31-63. https://doi.org/10.1016/B978-0-12-385007-2.00002-4.

Jadhav, S.R., Shah, R.M., Karpe, A.V., Morrison, P.D., Kouremenos, K., Beale, D.J. and Palombo, E.A., 2018. Detection of foodborne pathogens using proteomics and metabolomics-based approaches. Frontiers in Microbiology 9: 3132. https:// doi.org/10.3389/fmicb.2018.03132

Jasson, V., Jacxsens, L., Luning, P., Rajkovic, A. and Uyttendaele, M., 2010. Alternative microbial methods: an overview and selection criteria. Food Microbiology 27: 710-730. https://doi. org/10.1016/j.fm.2010.04.008

Keramas, G., Bang, D.D., Lund, M., Madsen, M., Bunkenborg, H., Telleman, P. and Christensen, C.B.V., 2004. Use of culture, PCR analysis and DNA microarrays for detection of Campylobacter jejuni and Campylobacter coli from chicken faeces. Journal of Clinical Microbiology 47: 3985-3991. https://doi.org/10.1128/ JCM.42.9.3985-3991.2004.

Law, J.W.-F., Ab Mutalib, N.-S., Chan, K.-G. and Lee, L.-H., 2015. Rapid methods for the detection of foodborne bacterial pathogens: principles, applications, advantages and limitations. Frontiers in Microbiology 5: 770. https://doi.org/10.3389/ fmicb.2014.00770

Li, H. and Zhu, J., 2017. Targeted metabolic profiling rapidly differentiates Escherichia coli and Staphylococcus aureus at species and strain level. Rapid Communications in Mass Spectrometry 31: 1669-1676. https://doi.org/10.1002/rcm.7949

Lüdin, P., Rando, G. and Sahi, B., 2018. Nouveau test rapide pour la détection des contrefaçons de fromages. Alimenta 10: 20-21. (In French Language). Available at: https://uploads.strikinglycdn.com/files/fe0d684e-50ab-4e83-a14c-97c31e73ea4e/ SwissDeCode_Artikel\%20DNA\%20Foil_Alimenta.pdf. Accessed 27 January 2021.

Magistrado, P., Carcia, M. and Raymundo, A., 2001. Isolation and polymerase chain reaction-base detection of Campylobacter jejuni and Campylobacter coli from poultry in Philippines. International Journal of Food Microbiology 70: 194-206. https:// doi.org/10.1016/S0168-1605(01)00537-2

Mandal, P., Biswas, A., Choi, K. and Pal, U., 2011. Methods for rapid detection of foodborne pathogens: an overview. American Journal of Food Technology 6: 87-102. https://doi.org/10.3923/ ajft.2011.87.102

Mayo Clinic, 2019. Salmonella infection. Oct. 11, 2019. Available at: https://www.mayoclinic.org/diseases-conditions/salmonella/ symptoms-causes/syc-20355329. Accessed 27 January 2021.

Mayo Clinic, 2020a. Listeria infection. Jan. 18, 2020. Available at: https://www.mayoclinic.org/diseases-conditions/listeriainfection/symptoms-causes/syc-20355269. Accessed 27 January 2021.
Mayo Clinic, 2020b. Shigella infection. Nov. 12, 2020. Available at: https://www.mayoclinic.org/diseases-conditions/shigella/symptoms-causes/syc-20377529. Accessed 27 January 2021.

Mayo Clinic, 2020c. Toxoplasmosis. Oct.13,2020. Availableat:https:// www.mayoclinic.org/diseases-conditions/toxoplasmosis/ symptoms-causes/syc-20356249. Accessed 27 January 2021.

Meat and Livestock Australia Limited (MLA), 2018. Evaluation of novel DNA-based test kits. Final report ABN 39081678364 (MLA). Meat \& Livestock Australia Limited, North Sydney.

Mirmajlessi, S.M., Destefanis, M., Gottsberger, R.A., Mänd, M. and Loit, E., 2015. PCR-based specific techniques used for detecting the most important pathogens on strawberry: a systematic review. Systematic Reviews 4: 9. https://doi. org/10.1186/2046-4053-4-9

Myint, M.S., Johnson, Y.J., Tablante, N.L. and Heckert, R.A., 2006. The effect of pre-enrichment protocol on the sensitivity and specificity of PCR for detection of naturally contaminated Salmonella in raw poultry compared to conventional culture. Food Microbiology 23: 599-604. https://doi.org/10.1016/j. fm.2005.09.002

NCBI (National Centre for Biotechnology Information), 2016. Entamoebiasis. Available at: https://www.ncbi.nlm.nih.gov/ mesh/68004749. Accessed 27 January 2021.

NCBI (National Centre for Biotechnology Information), 2017. Available at: https://www.ncbi.nlm.nih.gov/genome. Accessed 27 January 2021.

Ontario Ministry of Health and Long-Term Care, 2018. Yersiniosis. Last Modified: 2018-08-08. Available at: http://www.health.gov. on.ca/en/public/publications/disease/yersiniosis.aspx. Accessed 27 January 2021.

Ontario Ministry of Health and Long-Term Care, 2020. Campylobacteriosis. Last Modified: 2020-09-09. Available at: http://www.health.gov.on.ca/en/public/publications/disease/ campylobacter.aspx. Accessed 27 January 2021.

Park, K., 2015. Park's textbook of preventive and social medicine. 23rd ed. Banarsidas Bhanot Publishers, Jabalpur, India.

Pinu, F.R., 2016. Early detection of food pathogens and food spoilage microorganisms: application of metabolomics. Trends in Food Science \& Technology 54: 213-215. https://doi.org/10.1016/j. tifs.2016.05.018

Rajapaksha, P., Elbourne, A., Gangadoo, S., Brown, R., Cozzolino, D. and Chapman, J., 2019. A review of methods for the detection of pathogenic microorganisms. Analyst 144: 396-411. https://doi. org/10.1039/c8an01488d

Rasetti-Escargueil, C., Lemichez, E. and Popoff, M.R., 2020. Public health risk associated with botulism as foodborne zoonoses. Toxins (Basel) 12: 17. https://doi.org/10.3390/toxins12010017

Reta, D.H., Tessema, T.S., Ashenef, A.S., Desta, A.F., Labisso, W.L., Gizaw, S.T., et al. 2020. Molecular and immunological diagnostic techniques of medical viruses. International Journal of Microbiology 2020: 8832728. https://doi.org/10.1155/2020/8832728

Rossen, L., Norskov, P., Holmstrom, K. and Rasmussen, O.F., 1992. Inhibition of PCR by components of food samples, microbial diagnostic assays and DNA extraction solutions. International Journal of Food Microbiology 17: 37-45. https:// doi.org/10.1016/0168-1605(92)90017-W 
Singh, A.K., Ulanov, A.V., Li, Z., Jayaswal, R.K. and Wilkinson, B.J., 2011. Metabolomes of the psychrotolerant bacterium Listeria monocytogenes $10403 \mathrm{~S}$ grown at $37^{\circ} \mathrm{C}$ and $8^{\circ} \mathrm{C}$. International Journal of Food Microbiology 148: 107-114. https://doi. org/10.1016/j.ijfoodmicro.2011.05.008

Singhal, N., Kumar, M., Kanaujia, P.K. and Virdi, J.S., 2015. MALDITOF mass spectrometry: an emerging technology for microbial identification and diagnosis. Frontiers in Microbiology 6: 791. https://doi.org/10.3389/fmicb.2015.00791

Toscano, M., de Grandi, R. and Drago, L., 2018. Proteomics: the new era of microbiology. Microbiologia Medica 32: 7348. https://doi. org/10.4081/mm.2017.734.8

Tyco Integrated Security, 2012. Recall: the food industry's biggest threat to profitability. Food Safety Magazine October 11, 2012. Available at: https://www.food-safety.com/articles/2542-recall-the-foodindustrys-biggest-threat-to-profitability. Accessed 27 January 2021.

USDA ERS (United States Department of Agriculture Economic Research Service), 2014. Cost estimates of foodborne illnesses. Last updated: Tuesday, August 20, 2019. Available at: https:// www.ers.usda.gov/data-products/cost-estimates-of-foodborne-illnesses.aspx\#48446. Accessed 1 January 2021.

Valderrama, W.B., Dudley, E.G., Doores, S. and Cutter, C.N., 2016. Commercially available rapid methods for detection of selected food-borne pathogens. Critical Reviews in Food Science and
Nutrition 56: 1519-1531. https://doi.org/10.1080/10408398.20 13.775567

WHO (World Health Organization), 2020. Food safety. 30 April 2020. Available at: https://www.who.int/news-room/fact-sheets/ detail/food-safety. Accessed 27 January 2021.

WHO (World Health Organization), 2021. Foodborne diseases. Available at: https://www.who.int/health-topics/foodborne-diseases\#tab=tab_1. Accessed 27 January 2021.

Wilson, I.G., 1997. Inhibition and facilitation of nucleic acid amplification. Applied and Environmental Microbiology 63: 37413751. https://doi.org/10.1128/AEM.63.10.3741-3751.1997

Wu, F., Zhong, F. and He, F., 2016. Microbial proteomics: approaches, advances, and applications. Journal of Bioinformatics, Proteomics and Imaging Analysis 2: 85-91. https://doi.org/10.15436/2381-0793.16.004.

Yang, Y., Hu, M., Yu, K., Zeng, X. and Liu, X., 2015. Mass spectrometry-based proteomic approaches to study pathogenic bacteria-host interactions. Protein \& Cell 6: 265-274. https:// doi.org/10.1007/s13238-015-0136-6

Zhao, X., Lin, C.-W., Wang, J. and Oh, D.H., 2014. Advances in rapid detection methods for foodborne pathogens. Journal of Microbiology and Biotechnology 24: 297-312. https://doi. org/10.4014/jmb.1310.10013 